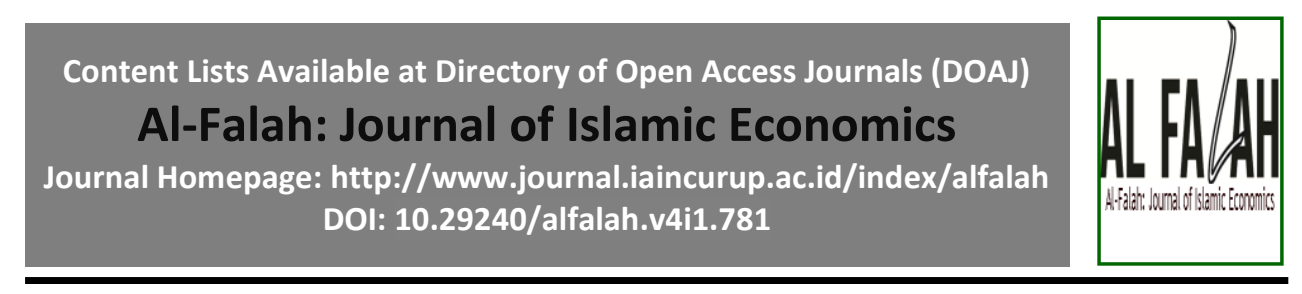

\title{
Abu Ubaid sebagai Fuqaha'dan Ekonom: Critical Reading terhadap Corak Pemikiran dan Konsepsi Ekonomi Ibn Ubaid
}

\author{
Taufik Hidayat ${ }^{\mathrm{a}^{*}}$ \\ a Sekolah Tinggi Agama Islam (STAI) Al-Falah,Air Molek-Riau, Indonesia \\ *E-mail Address: taufik_dayat15@yahoo.com
}

\begin{tabular}{l}
\hline ARTICLE INFO \\
\hline Article History: \\
Received 19-03-2019 \\
Revised 29-03-2019 \\
Accepted 16-05-2019
\end{tabular}

Keywords:

Jurist

Fragmented

Social Justice

Public Finance

Hermeneutics

Economic justice

Paper Type:

Conceptual Paper

\section{$\underline{A B S T R A C T:}$}

Purpose: The purpose of this article is to critically examine the style of thought and economic conception offered by Ibn Ubaid, in his Al-Amwal work. This critical reading is intended so that the scientific structure of Islamic economics presented in the book of Al-Amwal, can be identified more firmly and clearly.

Design/Methodology/Approach: This paper explores critically the economic conception of Ibn Ubaid, and then formulates how the style of thinking Ibn Ubaid. With a qualitative approach, with the design ofresearch hermeneutics, this paper is expected to be able to interpret Ibn Ubaid's thinking more systematically.

Findings: This study offers two theses: First, from the work and structure of the arguments found consistently in the book of Al-Amwal, Ibn Ubaid is actually the figure of a prolific jurist. He consistently uses fiqh reasoning in elaborating an economic issues. Second, the economic concepts offered by Ibn Ubaid are fragmented, or fragmented. He is more concerned with discussing public finance. He offers the concept of a tax system based on social justice, or tax collection must be based on a fair system. So that taxes are not an instrument of exploitation of the people.

Originality/Value: The contribution of this paper lies in the answer to the emptiness of the literature that critically examines the book of $\mathrm{Al}$ Amwal, and is able to identify the dominant patterns of thought of Ibn Ubaid.

\section{ABSTRAK:}

Tujuan: Tujuan artikel ini untuk mengkaji secara kriris corak pemikiran dan konsepsi ekonomi yang ditawarkan oleh Ibn Ubaid, dalam karyanya Al-Amwal. Pembacaan kritis ini ditujukan agar struktur pengilmuan ekonomi Islam yang 
dipaparkan pada kitab Al-Amwal, dapat diidentifikasi lebih tegas dan jelas.

Desain/Metode/Pendekatan:Tulisan ini mengekplorasi secara kritis konsepsi ekonomi Ibn Ubaid, dan kemudian merumuskan bagaimana corak pemikiran Ibn Ubaid. Dengan pendekatan kualitatif, dengan design penelitian hermeneutics, tulisan ini diharapkan mampu menafsirkan pemikiran Ibn Ubaid lebih sistematis.

Temuan: Kajian ini menawarkan dua tesis: Pertama, dari karya dan struktur argumentasi yang ditemukan secara konsisten dalam kitab Al-Amwal, Ibn Ubaid sesungguhnya adalah sosok seorang jurist yang prolific. Sehingga dengan konsisten ia menggunakan nalar fiqh dalam mengelaborasi isu-isu ekonomi. Kedua, konsep ekonomi yang ditawarkan oleh Ibn Ubaid bersipat fragmented, atau terfragmentasi. Ia lebih concern membahas keuangan publik. Ia menawarkan konsep tax system based on social justice, atau pemunggutan pajak mesti didasarkan pada sistem yang berkeadilan. Agar pajak tidak menjadi instrumen eksploitasi terhadap umat.

Originalitas/Novelty: Kontribusi tulisan ini terletak pada jawabannya terhadap kekosongan literatur yang mengkaji secara kritis terhadap kitab Al-Amwal, dan mampu mengidentifikasi corak pemikiran dominan seorang Ibn Ubaid.

\section{PENDAHULUAN}

Bila kita pahami perkembangan pemikiran ekonomi, maka para ahli ekonomi konvensional menyetujui bahwa Adam Smith adalah pelopor ekonomi modern. Dari pemikiran Smith itu muncullah tradisi pemikiran ekonomi klasik yang menekankan pada kebebasan mekanisme pasar dalam mengukur aktivitas ekonomi (laises faire) tanpa perlu diintervensi oleh kebijakan pemerintah. Didalam perkembangannya, pemikiran ekonomi klasik ternyata tidak selalu dapat menyelesaikan persoalan ekonomi yang berkembang. Ini dibuktikan dengan timbulnya depresi perekonomian dunia menjelang perang dunia II. ${ }^{1}$

Maka dari sinilah muncul para pemikir ekonomi yang menekankan perlunya peran pemerintah dalam mengatur aktifitas ekonomi. Pada dasarnya, perkembangan ekonomi jika ditelusuri lebih jauh, maka akan dapat dipahami bahwa perkembangan itu sangat pesat sebelum Adam Smith muncul dan memperkenalkan pemikiran ekonomi lewat maqnum opus-nya, The Wealth of Nation. Bahkan bisa jadi pemikiran Smith merupakan redundant dari pemikiran ekonom ataupun filosuf sebelumnya. Indikasi ini semakin besar jika diperhatikan bagaimana perkembangan ekonomi Islam yang bila

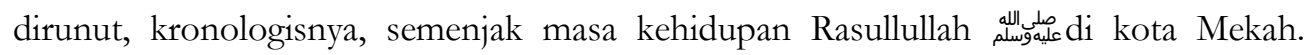
Namun pada waktu itu pemikiran mengenai ekonomi Islam belum berkembang dengan baik, hal ini disebabkan oleh masyarakat pada saat itu langsung mempraktikannya, dan

${ }^{1}$ Imamudin Yuliadi, Ekonomi Islam: Sebuah Pengantar, (Yokyakarta: LPPI, 2001), h. 28. 
apabila menemukan persoalan dalam bidang ekonomi maka mereka langsung mempertanyakan kepada Nabi.

Secara kontekstual, persoalan pada masa itu belum begitu komplek. Secara makro praktek ekonomi yang dilakukan Nabi لله dan para sahabat sarat dengan unsur economic justice dalam kerangka etika bisnis yang Qur'ani. ${ }^{2}$ Dasar ekonomi sesungguhnya adalah Al Qur'an dan Hadist yang kaya akan hukum-hukum dan pengarahan kebijakan ekonomi yang harus diambil dan disesuaikan dengan perubahan zaman dan perbedaan kawasan regional sampai saat sekarang ini. Pada awal Islam datang, kegiatan ekonomi yang sedang berjalan, tidak terlalu kompleks seperti sekarang ini. Konsekuensinya, hukum dan pemikiran ekonomi yang ada hanya mengakomodasi konsep current transaction, seperti konsep pertukaran barang, penentuan harga, konsep riba, ataupun konsep yang lainya. Seiring dengan ekspansi dakwah Islam, kawasan regional yang berada dibawah kekuasaan Islam menjadi semakin luas, maka fenomena tersebut tentu akan memicu perubahan terhadap kegiatan ekonomi masyarakat, hingga pada abad ke-15 upaya pengembangan dan elaborasi pemikiran ekonomi berdasarkan nilai dan prinsip syari'ah yang berlaku telah berubah dengan seksama.

Untuk menjabarkan bentuk dan konsep-konsep ekonomi yang berkembang di tengah-tengah masyarakat dewasa ini, maka munculah para pemikir-pemikir ekonomi Islam klasik yang mencoba menjawab kesenjangan yang ada ditengah-tengah masyarakat, yang mana salah satu pemikir cendikiawan muslim tersebut adalah (Abu Ubaid) yang mencoba mendalami isu ekonomi yang mana dalam konsep ekonominya, Ibn Ubaid lebih menekankan prinsip keadilan terhadap keuangan publik suatu negara. Karena itu kemudian dirinya menulis sebuah buku yang terkenal, yaitu kitab al Amwal, yang bisa dijadikan sebagai suplemen dalam kerangka memahami ekonomi Islam. Dalam konteks ini, maka tulisan ini akan concern mengkaji secara kritis corak pemikiran Ibn Ubaid, dalam mengelaborasi persoalan ekonomi Tidak hanya itu, tulisan ini juga akan mengelaborasi secara kritis konsep penting ekonomi yang dipaparkan oleh Ibn Ubaid dalam karyanya, Al-Amwal. Dengan demikian, kajian itu tidak hanya diproyeksikan sebagai literatur tetapi juga diposisikan sebagai ulasan kritis bagaimana pemikiran dan konsepsi ekonomi Ibn Ubaid.

\section{METODOLOGI}

Artikel ini menerapkan pendekatan hermeneutika untuk memahami teks yang ditulis oleh Ibn Ubaid, yakni kitab Al-Amwal. Adapun hermeneutika merupakan pendekatan radikal dan reflektif-filosofis terhadap ide yang ada di balik sebuah teks. ${ }^{3}$ Karena artikel ini menjadikan teks yang ditulis oleh Ibn Ubaid, sebagai unit analisis, maka pendekatan hermeneutika sebagai design kajian dipilih dan diterapkan secara intens. Hal ini sesuai dengan pandangan Mohammad Ali Kharmandar; Amin Karimnia

\footnotetext{
${ }^{2}$ h. 28 .

${ }^{3}$ Iasmina Petrovici, "Philosophy as Hermeneutics: The World of Text Concept in Paul Ricouer's Hermeneutics," in Procedia - Social and Behavioral Sciences, vol. 71 (International Workshop on the Historiography of Philosophy: Representations and Cultural Constructions 2012, Procedia - Social and Behavioral Sciences, 2013), h. 22.
} 
yang mengutarakan bahwa pembacaan terhadap teks akan lebih akurat, dan sensitif jika menggunakan pendekatan hermeneutika. ${ }^{4}$ Karena hermeneutika tidak hanya mampu memotret teks sebagai susunan tulisan. Tapi mampu memahami ide di balik sebuah teks.

Tugas hermeneutika adalah mengungkap makna, ide dan nilai-nilai yang ada pada sebuah teks. ${ }^{5}$ Demikian juga pendekatan hermeneutika difungsikan dalam artikel ini. Dalam penerapannya, dengan merujuk pada Gadamer, seorang pengkaji sebuah teks mestilah mampu membedakan teks dari maksud yang dituju oleh pengarangnya. Dalam konteks ini, peneliti akan aktif memberikan makna terhadap sebuah teks sesuai dengan kontek pengalaman yang melekat pada pembaca. Ini kemudian disebut dengan pembauran cakrawala-perpaduan antara cakrawala masa lalu saat sebuah teks itu ditulis dan cakrawala saat teks tersebut dibaca, dan dipahami oleh pembaca. ${ }^{6}$ Proses pembauran ini yang secara konsisten dilakukan pada setiap tema, dan bab yang terdapat dalam kitab Al-Amwal. Hanya saja dalam memahami kitab dan pemikiran Ibn Ubaid tersebut, peneliti juga merujuk secara eksploratif terhadap 'tafsir' yang muncul terhadap pemikiran Ibn Ubaid.

\section{TEMUAN DAN PEMBAHASAN}

\section{Riwayat Hidup}

Dia adalah Al Qasim bin Sallam bin Miskin bin Zaid Al- harawi Al-Azadi AlBagdady. Dia lahir pada tahun $150 \mathrm{H}$ di kotaHarrah, Khurasan, sebelah barat laut Afganistan. Ayahnya keturuna Bizantyum yang menjadi maula suku azad. Setelah memperoleh ilmu yang memadai di kota kelahiranya, pada umur 20 tahun, Abu Ubaid pergi berkelana menuntut ilmu ke berbagai kota, seperti Kufah, Basrah dan Baqhdad. Ilmu-ilmu yang dipelajarinya antara lain mencakup ilmu tata bahasa Arab, Qira'at, Tafsir, Hadist dan Fiqh. Pada tahun 192 H, akhirnya Abu Ubaid diangkat sebagai qadi (hakim) di daerah Tarsus sampai pada tahun 210H, oleh Tsabit bin Nasr Al-Malik (gubenur Thugur pada masa khalifah Harun Ar Rasyid). Akhirnya dia tinggal menetap di Baqdad selama 10 tahun. Pada tahun $219 \mathrm{H}$, setelah berhajji ia menetap di Mekkah dan dia wafat pada $224 \mathrm{H}$.

Abu Ubaid hidup pada masa khalifah Daulah Abassyah, yakni pada masa Khalifah al Mahdi (158/775 M). Dalam penelitian Najatullah Siddiqi, masa al Mahdi ini ditemukan tiga tokoh terkenal yang menuliskan karya dalam bidang ekonomi, sedangkan pada masa Abasiyah pertama ini, ditemukan lebih dari 200 orang pemikir yang terdiri selain fuqaha juga filusufis, masa Abasiyah ini merupakan kegemilangan dunia Islam atau masa renaisance. Dengan tidak meninyimpang dari nilai keadilan dan keberadaban, Abu Ubaid lebih secara historis mementingkan aspek rasionalitas, nalar

${ }^{4}$ Mohammad Ali Kharmandar Amin Karimnia, "The Fundamentals of Constructing a Hermeneutical Model for Poetry Translation," in Procedia - Social and Behavioral Sciences, vol. 70 (Akdeniz Language Studies Conference 2012, Procedia - Social and Behavioral Sciences, 2013), h. 580 .

5 Bambang Hendarta Suta Purwana, "Pendekatan Hermeneutik Dalam Penafsiran Teks Sastra Melayu," Humaniora XIII, no. 1 Februari (2001): h. 82.

${ }^{6}$ h. 85 . 
dan spritual terhadap kehidupan manusia, baik sebagai individu maupun masyarakat. Atas dasar itu, Abu Ubaid menjadi salah seorang pioner yang menawarkan nilai-nilai tradisional pada abad ke III H, yang mana ia berpendapat bahwa revitalisasi dari sistem perekonomian, dapat diupayakan melalui reformasi terhadap akar-akar kebijakan keuangan serta institusi ekonomi dengan di dasarkan berdasarkan Quran dan Hadis. Dengan kata lain, bersumber dari yang suci--Quran dan Hadis, guna mendapatkan nilai-nilai eklusif serta yang kemudian diimplementasikan pada pemikiran ekonomi

\section{Corak Pemikiran Abu Ubaid}


Abu Ubaid merupakan seorang ahli hadis dan ahli fiqh terkemuka dimasa hidupnya. Selama menjabat sebagai Qadi di Tarsus, dia sering menangani berbagai kasus pertanahan dan perpajakan serta menyelesaikannya dengan baik. Juga dia merupakan ahli bahasa. Karenanya ia banyak menterjemahkan karya dari bahasa Persi ke Bahasa Arab.

Sisi lain dari Ibn Ubaid terungkap dari frekuensi yang amat sering mengunakan kalimat amr dalam kitab al Amwal. Tampaknya pemikiran Abu Ubaid dipengaruhi oleh pemikiran Abu Amr Abdurrabman ibn amr al Awza'i, serta ulama-ulama Suriah lainnya sewaktu dia menjadi Qadi di Tarsus. Bila dibandingkan dengan pemikiran Abu Yusuf, maka Abu Ubaid tidak menelik masalah-masalah kelemahan sistem pemerintahan serta penanggulanganya, namun Abu Ubaid kitab Al Amwal dapat dikatakan lebih kaya dari pada Kitab al Kharaj. Dalam hal ini Abu Ubaid lebih terfokus pada permasalahan yang berkaitan dengan standar etika politik suatu pemerintahan ketimbang berorientasi pada teknik efesiensi pengelolaan, Abu Ubaid lebih concern kepada masalah restributif dari sisi "apa" daripada "bagaimana".

Filosofi yang dikemukakan Abu Ubaid hanya merupakan sebuah pendekatan yang bersifat profesional yang bersandar pada kemampuan teknis, dan tidak menyimpang dari prinsip-prinsip keadilan dan masyarakat beradab. Pandangan Abu Ubaid mengedepankan dominasi intelektualitas islami serta bersifat teologis. Ini menjadi fondasi bagi kehidupan manusia di dunia dan akhirat, baik individu maupun sosial, sehingga dengan pola seperti itu, akhirnya Abu Ubaid berhasil menjadi salah seorang cendikiawan Muslim terkenal pada abad ke-3H yang menetapkan revitalisasi system perekonomian berdasarkan Qur'an dan Hadis, yang dilakukan melalui reformasi kebijakan keuangan dan institusinya. ${ }^{8}$

Dengan pengetahuan dan wawasan yang dimiliki Abu Ubaid yang begitu luas, sehingga dia dinisbahkan oleh ulama Syafi'iyah dan Hanabilab sebagai pengikut mereka, walaupun fakta-fakta menunjukkan Abu Ubaid adalah seorang fuqaha yang independen. Namun dalam kitab al Amwal, Abu Ubaid tidak pernah menyebut kedua nama ulama Syafiiyah dan Hanabilah, tetapi sebaliknya, Abu Ubaid sering kali mengutip pandangan Malik ibn Anas (salah seorang guru Al Syafi'i) dan begitu juga dia sering mengutip beberapa ijtihad Abu Hanifah, Abu Yusuf dan Mubammad ibn Hasan al Syaibani, bahkan hampir seluruh pendapat mereka dia tolak. ${ }^{9}$

Jika isi dari buku Abu Ubaid dievalusi dari sisi filsafat hukum maka akan tampak bahwa Abu Ubaid menekankan keadilan sebagai prinsip utama. Baginya, pengimplementasian dari prinsip ini akan membawa kepada kesejahteraan ekonomi dan prinsip ini akan membawa kepada kesejahteraan pendekatan yang selaras dengan sosial. Pada dasarnya ia memiliki pendekatan yang berimbang pada hak-hak individual, publik dan negara, jika kepentingan individu berbenturan dengan kepentinan publik, maka ditekankan lebih dahulu kepentingan publik.

Tulisan-tulisan Abu Ubaid ditulis dan dihasilkan pada masa Dinasti Abassiyah, dan tidak pernah ada masalah legitimasi, meski pemikirannya sering menyoroti

${ }^{7}$ Natajuddin Siddiqi, Muslim Economics Thinking (Leicester: 1981, Islamic Fondation), h. 132.

8 Adiwarman A. Karim, Sejarah Pemikiran Ekonomi Islam (Jakarta: Raja Garafindo Persada, 2004), h. 224.

9 Sejarah Pemikiran Ekonomi Islam. 
kebijakan khalifah untuk mebuat keputusan dengan hati-hati. Sebagai contoh, Abu Ubaid berpendapat bahwa zakat dari tabungan dapat diberikan pada negara ataupun penerimaannya sendiri, sedangkan zakat komoditi harus diberikan kepada pemerintah. Jika tidak, maka kewajiban agama diasumsikan tidak tertunaikan. Lebih jauh, pengakuannya terhadap otoritas Imam dalam memutuskan kepentingan publik seperti membagi tanah taklukkan. Para penakluk didorong untuk membiarkan kepemiliknnya diambil alih oleh penduduk setempat.

Abu Ubaid juga membahas tentang masalah tarif dasar pajak tanah atau polltax, dia juga menyinggung tentang pentingnya keseimbangan antara kekuatan finansial dari subyek non Muslim, dalam finansial modern disebut sebagai "capacity to pay"(kemampuan membayar) dan juga memperhatikan kepentingan para penerima dari kalangan Muslim. Menurut Abu Ubaid, dia membela pendapatan bahwa tarif pajak kontraktual tidak dapat dinaikan tapi dapat diturunkan jika terjadi kemampuan membayar dengan berkesinambungan.

Lebih jauh Abu Ubaid mengatakan jika permohonan pembebasan hutang disaksikan oleh saksi Muslim, maka komoditas komersial subyek Muslim serta hutangnya itu akan dibebaskan dari pajak/cukai (duty free). Abu Ubaid juga menjelaskan tentang pengumpulan kharaj, jizyah, ushur atau zakat tidak boleh menyiksa seseorang dan disisi lain orang tersebut harus melunasi kewajiban finansialnya secara teratur, dan Abu Ubaid merusaha untuk menghentikan terjadinya diskriminasi dalam perpajakan serta menghindari pajak (tax evasion).

Dalam beberapa permasalahan, Abu Ubaid tidak merujuk kepada kharaj yang dipelopori oleh khalifah Umar bin Khatab, ia memandang bahwa adanya permasalahan dalam meningkatkan atau menurunkannya berdasarkan kepada situasi dan kondisi, karena Abu Ubaid mengadopsi kaedah yang mengatakan "la yunkaru taqhaiyyiru al fatwa bi taqhayyur al azminab”, namun walaupun keragaman terjadi tapi keputusan/ijtihad harus sesuai dengan nash yang berlaku

\section{Sekilas Tentang Kitab Al Amwal}

Kitab al Amwal dibagi kedalam beberapa bagian dan bab yang tidak beraturan isinya, dalam bab pendahuluan, maka Abu Ubaid secara singkat membahas tentang hak dan kewajiban pemerintah terhadap rakyatnya serta sebaliknya, dengan penekanan terhadap kebutuhan suatu pemerintah yang adil. Pada bagian selanjutnya kitab ini membahas tentang berbagai jenis pemasukan negara yang dipercayakan kepada pemimpin atas nama rakyat serta berbagai landasan hukum yang sesuai dengan Alqur'an dan Hadist. Dalam bab tersebut, Abu Ubaid menekankan pembahasanya kedalam pendapatan negara yang menjadi hak Rasulullah, seperti harta fai, bagian khumus dan safi' serta pengalokasiannya, baik dimasa rasul itu sendiri maupun sesudahnya. Jadi pada bagian selanjutnya, ketiga hal tersebut menjadi kerangka dasar pemikiran dalam kitab itu, ketika membahas tiga sumber utama pendapatan negara, yaitu fai, khumus dan shadaqah yang merupakan kewajiban pemerintah untuk mengurus dan mendristibusikannya kepada masyarakat.

Tiga bagian dalam kitab al-Amwal tersebut meliputi beberapa bab yang membahas masalah penerimaan fai. Menurut Abu Ubaid, harta fai merupakan pendapatan negara yang diambil oleh orang muslim terhadap harta non-muslim yang 
diambil dengan jalan damai, berasal dari jiayah, kharaj dan ushur. ${ }^{10}$ Dan pada bagian keempat dalam kitab tersebut, sesuai dengan perluasan daerah Islam di masa dahulu, maka itu dibahas mengenai pertahanan, administrasi, hukum internasional, dan hukum perang, bagian kelima membahas tentang distribusi, pendapatan fai, bagian keenam dalam kitab tersebut membahas tentang iqta, ibya al mawat. ${ }^{11}$

Jadi dapat kita tarik suatu kesimpulan bahwa isi bagian dari kitab al Amwal tersebut lebih mendalam membahas masalah Keuangan Publik (Public Finance), secara umum. Pada masa Abu Ubaid masih hidup, pertanian dipandang sebagai usaha yang paling baik dan utama, karena fungsi utamanya untuk menyediakan kebutuhan dasar, makanan dan juga merupakan sumber utama pendapatan negara, maka hal inilah yang menjadikan sektor pertanian sebagai isu utama, bukan masalah pertumbuhan ekonomi. Sebab itu, Abu Ubaid memfokuskan kajiannya pada persoalan sosio-politik-ekonomi yang stabil dan adil.

Secara umum isi dari kitab al Amwal tersebut didominasi oleh Hadis Nabi. Kendati demikian kitab al Amwal membahas pilar dan fondasi agar suatu pemerintah sukses dalam menerapkan berbagai kebijakannya, seperti dalam pemerintahan Khalifah Umar ibn Khatab, yang berhasil membangun sistem perpajakan dan Umar ibn Abdul Aqiz. yang berhasil dalam memperbaiki dan menata ulang sistem perpajakan agar lebih baik. ${ }^{12}$

Salah seorang murid Abu Ubaid, yaitu Ibrabim al Harbi, mengkritik gurunya dan menilai bahwa kitab al Amwal merupakan karangan Abu Ubaid yang paling lemah karena sedikitnya hadis-hadis yang beliau bahas, namun hal ini dapat dipahami. Karena Abu Ubaid hanya menulis hadis-hadis yang sangat relevan. Sebab dalam beberapa kesempatan ia menyebutkan terdapat hadis-hadis yang berjumlah lebih banyak dari pada yang dia bahas. Dan juga Abu Ubaid dikenal sebagai seorang mujtabid yang independen karena kehandalannya dalam melakukan istinbath hukum dari Alqur'an dan Hadis, yang dapat menghasilkan suatu kaedah-kaedah tentang keuangan, terutama yang berkaitan dengan perpajakan. ${ }^{13}$ Selain itu Abu Ubaid berpendapat bahwa Qur'an dan Hadis merupakan referensi utama dalam menarik suatu kesimpulan hukum. Qur'an juga merupakan pondasi dasar yang lebih tinggi dari Hadis dan salah satu fungsi Hadis adalah sebagai penjelasan bagi Alqur'an itu sendiri.

${ }^{10}$ Said Sa'ad Marthon, Ekonomi Islam: Di Tengah Krisis Ekonomi Global (Jakarta: Zikrul Hakim, 2008), h. 97.

${ }^{11}$ Ekonomi Islam: Di Tengah Krisis Ekonomi Global.

12 Abdul Islahi Azim, History of Economic Thought in Islam (Aligarh: Aligarh Muslim University, 1996), h. 118.

${ }^{13}$ Sejarah Pemikiran Ekonomi Islam, h. 249. 


\section{Dikotomi Masyarakat Desa dan Kota}

Abu Ubaid menegaskan bahwa berbeda dengan kaum Badui, kaum Urban atau perkotaan, antara lain: Pertama, ikut dalam melangsungkan Negara dengan berbagi kewajiban administrasi dari semua kaum muslimin. Kedua, memelihara dan menjaga serta memperkuat pertahanan sipil melalui mobilisasi jiwa dan harta benda mereka. Ketiga, mempopulerkan pendidikan dan pengajaran melalui pembelajaran dan pengajaran al-Qur'an dan Hadist dengan disemenisasi keunggulan kwalitas isnya. Keempat, Melakukan konstribusi terhadap keseimbangan sosial melalui pemberian dan penerimaan budud.

Jadi dapat dipahami bahwa disamping konsep utama yang diterapkan Abu Ubaid adalah (keadilan). Abu Ubaid juga mengembangkan suatu negara Islam berdasarkan kepada administrasi pertahanan, pendidikan, hukum dan ketaatan. Karakteristik demikian menurutnya hanya diberikan oleh Allah kepada kaum Urban. Kaum Badui biasanya tidak mempunyai kewajiban publik sebagaimana kewajiban kaum Urban. Mereka tidak dapat menerima mamfaat penerimaan harta fai dan menerima tunjangan dari negara seperti kaum Urban. Karena mereka memiliki hak klaim sementara terhadap penerimaan fai hanya ada pada waktu terjadinya tiga kondisi krisis-saat invansi atau penyerangan musuh, kekeringan yang mematikan serta kerusuhan sipil.

Abu Ubaid memperluas aturan ini untuk diterapkan pada masyarakat pegunungan dan pedesaan, sementara ia memberikan kepada masyarakat, seperti anakanak perkotaan mendapat hak yang sama dengan orang dewasa terhadap tunjangan walupun kecil, dan itu berasal dari harta fai yang mungkin dibagikan karena dia mengira bahwa mereka sebagai penyumbang potensial terhadap kewajiban publik yang terkait dimasa yang akan datang. Abu Ubaid mengakui adanya hak para budak terhadap arzaq (jatah) yang bukan tunjangan.

\section{Konsep dan Teori Ekonomi Abu Ubaid}

\section{Filosofis Hukum-Ekonomi}

Bila kita pelajari isi dari Kitab al Amwal, maka secara filosofis hukum akan jelas bahwa Abu Ubaid menekankan keadilan sebagai prinsip utama. Bagi Abu Ubaid, pengimplementasian dari prinsip-prinsip ini akan membawa kepada kesejahteraan ekonomi dan keselarasan sosial. ${ }^{14}$ Dan juga bagi Abu Ubaid memiliki pendekatan yang seimbang terhadap hak-hak individu, publik dan negara, jika seandainya kepentingan individu berbenturan dengan kepentingan publik, maka bagi Abu Ubaid didahulukan kepentingan publik. ${ }^{15}$

Pada masa keemasan Islam, yaitu pada masa Dinasti Abassiah, maka Abu Ubaid menitik beratkan tulisannya pada masalah yang berkaitan dengan khalifah dalam rangka mengambil suatu kebijakan dalam memutuskan suatu perkara selama tidak bertentangan dengan ajaran Islam dan kepentingan masyarakat. Sehingga dengan demikian, Abu Ubaid menyatakan bahwa zakat tabungan dapat diberikan kepada negara atau pribadi penerima secara langsung, tapi bagi zakat komoditas harus

${ }^{14}$ Sejarah Pemikiran Ekonomi Islam, Euis Amalia (Jakarta: Pustaka Asatrus, 2005), h. 103.

\footnotetext{
${ }^{15}$ Ekonomi Islam: Di Tengah Krisis Ekonomi Global, h. 95.
} 
diberikan kepada pemerintah dan jika tidak, maka kewajiban agama diasumsikan tidak dilaksanakan.

Di sisi lain, Abu Ubaid juga menekankan bahwa perbendaharaan negara tidak boleh disalahgunakan atau dimamfaatkan untuk kepentingan pribadi. Dengan kata lain, perbendaharaan negara harus digunakan untuk kepentingan publik. Ketika membahas masalah pajak atau kharaj dan jisyah, dia menyinggung tentang pentingnya keseimbangan antara kekuatan finansial penduduk non Muslim dengan kepentingan dari golongan Muslim yang berhak menerimanya. ${ }^{16}$

Abu Ubaid juga menyatakan bahwa tarif pajak kontraktual tidak dapat ditunaikan, bahkan dapat diturunkan apabila terjadi ketidakmampuan membayarnya. Jika seorang penduduk non Muslim mengajukan permohonan bebas utang dan dibenarkn oleh saksi Muslim, maka barang perdagangan mereka tersebut yang setara dengan jumlah utangnya, sehingga mereka itu akan terbebas dari bea cukai. Dalam masalah pemungutan kharaj, jisyah, ushur dan zakat, Abu Ubaid tidak memaksa masyarakat agar memenuhi kewajiban finansialnya secara teratur dan seharusnya, dengan kata lain, Abu Ubaid menghentikan system diskriminasi dan eksploitasi serta dan penindasan dalam perpajakan serta upaya penghindari pajak.

Pandangan Abu Ubaid yang tidak merujuk kepada tingkat kharaj yang diterapkan oleh Khlifah Umar terhadap permasalahan yang muncul dari kebijakan peningkatan dan penurunan tingkat kharaj berdasarkan situasi dan kondisi, ${ }^{17}$ ini menunjukan bahwa Abu Ubaid menggunakan kaedah fiqh "la yunkaru taghayyuru al-fatwa bi taghayyuril azmani", namun demikian, baginya, keberagaman tersebut hanya berlaku aturan hukum atau hukum tersebut diputuskan melalui suatu ijtihad.

\section{Kepemilikan dan Kebijakan Pertania}

Dalam sistim perekonomian, Abu Ubaid mengakui adanya kepemilikan pribadi dan kepemilikan publik. Dalam hal kepemilikan ini Abu Ubaid berpendapat bahwa hubungan antara kepemilikan dengan kebijakan perbaikan pertanian, merupakan kebijakan pemerintah, seperti deklarasi resmi terhadap kepemilikan individual atas tanah tandus yang disuburkan, sebagai insentif untuk meningkatkan pruduksi pertanian. Karena itu tanah yang diberikan dengan persyaratan untuk diolah dan dibabaskan dari kewajiban pajak, jika dibiarkan menganggur selam tiga tahun berturut-turut akan di denda dan kemudian dialihkan kepemilikannya kepada penguasa. ${ }^{18}$ Bahkan dalam pandangan Abu Ubaid, sumber dari kesejahteraan publik, seperti air, padang rumput, dan api tidak boleh dimonopoli seperti hima' (pohon pribadi), maka seluruh sumber daya ini hanya dapat dimasukkan kedalam kepemilikan negara yang akan digunakan untuk memenuhi kebutuhan masyarakat.

\section{Distribusi Zakat berbasis Kebutuhan}

Abu Ubaid sangat menentang pandapat yang menyatakan bahwa pembagian zakat harus dilakukan secara merata diantara para kelompok penerima zakat dan

\footnotetext{
${ }^{16}$ Ekonomi Islam: Di Tengah Krisis Ekonomi Global.

${ }^{17}$ Ekonomi Islam: Sebuah Pengantar.

${ }^{18}$ Sejarab Pemikiran Ekonomi Islam, h. 256.
} 
cendrung menetukan suatu batas tertinggi terhadap bagian perorangan, namun bagi Abu Ubaid yang terpenting adalah memenuhi kebutuhan-kebutuhan dasar, berapapun besarnya, serta bagaimana menyelamatkan orang-orang dari bahaya kelaparan. Oleh sebab itu, pendekatan yang dilakukan oleh Abu Ubaid ini mengindikasikan bahwa ada tiga kelompok sosio-ekonomi yang terkait dengan status zakat, yaitu: 1) Kalangankaya yang terkena wajib zakat; 2) Kalanganmenengah yang tidak terkena wajib zakat, tapi juga tidak berhak menerima zakat; 3) Kalangan penerima zakat.

Berkaitan dengan distribusi zakat, Abu Ubaid mengadopsi prinsip "mendistribusikan kepada setiap orang menurut kebutubannya masing-masing", dan ketika membahas kebijakan penguasa dalam hal jumlah zakat/pajak yang diberikan kepada pengumpul zakat, pada prinsipnya Abu Ubaid menekankan implementasi prinsip "bagi setip orang sesuai dengan haknya". Karena zakat yang dibagikan kepada pengelola zakat harus sesuai dengan kebijakan imam.

\section{Fungsi Uang}

Abu Ubaid mengakui adanya dua fungsi uang, yang tida memiliki nilai instrinsik sebagai standar dari nilai pertukaran (standard of exchange value) dan sebagai media pertkaran (medium of exchange). Jelaslah bahwa pendekatan ini menunjukan adanya dukungan Abu Ubaid terhadap teori ekonomi mengenai uang logam.

Emas dan perak merupakan jenis alat tukar yang pertama sekali dipergunakan dalam sistem ekonomi Islam klasik. Ketika Nabi Muhammad diangkat sebagai Rasul, maka beliau menetapkan emas dan perak sebagai mata uang ahli Makah dan sekaligus mewajibkan zakat. ${ }^{19}$ Dalam kehidupan ekonomi, uang mempunyai peranan yang sangat penting, maka pada prinsipnya, Abu Ubaid mengakui ada dua fungsi uang diatas. Dalam hal ini, Abu Ubaid menyatakan;

"Ada hal yang tidak dapat diragukan lagi, bahwa emas dan perak tidak layak untuk apa pun kecuali menjadi harga dari barang dan jasa. Keuntungan tertinggi dapat diperoleb dari kedua benda ini adalah penggunaanya untuk membeli sesuatu. ,20

Pernyataan Abu Ubaid ini menunjukan bahwa ia mendukung teori konvensional mengenai uang logam, dia menelusuri kepada kegunaan umum dari nilai kedua benda tersebut dibandingkan dengan komoditas yang lainya, jika kedua benda tersebut juga digunakan pula sebagai komoditas, maka nilai kedua benda tersebut dapat berubah-ubah pula, karena dalam hal ini kedua benda tersebut akan memainkan dua peran yang berbeda, yaitu sebagai barang yang harus dinilai atau sebagai standar nilai terhadap barang-barang lainya. Maka secara implisit, Abu Ubaid mengakui adanya fungsi uang sebagai penyimpan nilai dari suatu barang. Salah satu ciri khas dari kitab al Amwal diantara kitab yang lainya adalah membahas masalah keuangan publik, dengan pembahasan yang elaboratif dan mendalam tentang timbangan dan ukuran, yang bisa digunakan dalam menghitung beberapa kewajiban agama yang berhubungan dengan harta.

Abu Ubaid menulis bab terpisah untuk menjelaskan problematika dan ijtihadnya tentang penimbangan dan pengukuran yang digunakan dalam menghitung kewajiban finansial. Terutama dalam kaitannya dengan memenuhi kewajiban agama dan dunia. Keistimewaan lain dari kitab Al Amwal, diantara buku-buku lain sejenis kitab 
tersebut. Dalam pembahasan tersebut diceritakan usaha kaalifah Abdul Malik bin Marwan dalam melakukan standarisasi dari berbagai mata uang yang ada dalam sirkulasi.

Pada epilog kitabnya kembali Abu Ubaid menekankan keadilan sebagai prinsip utama. Baginya, pengimplementasian dari prinsip ini akan membawa kepada kesejahteraan ekonomi dan keselarasan sosial. Secara umum, dan fundamental Abu Ubaid memiliki pendekatan yang berimbang kepada hak-hak individual, publik, dan negara. Bahkan ketika kepentingan individual berbenturan dengan kepentingan publik, maka Ibn Ubaid berpihak kepada kepemilikan publik. Abu Ubaid adalah peletak ode etik dan moral dalam hal distribusi keuangan publik (public finansial) secara adil.

Pemikiran Abu Ubaid menjadi rujukan bagi pengembangan dunia ekonomi modern, bahkan berdasarkan analisa para pemikir ekonomi Islam kontemporer, Adam Smith, dengan karyanya "The Wealth of Nation" sangat dipengaruhi oleh pemikiran Abu Ubaid yang ada dalam kitab al Amwal. Meskipun keduanya hidup dan berkembang dalam masa dan periode yang berbeda.

\section{SIMPULAN}

Uraian pada bagian terdahulu memungkinkan pengajuan tesis dalam artikel ini, dimana Abu Ubaid merupakan salah satu pakar pemikir ekonomi klasik, yang mana dia lebih cenderung membicarakan tentang masalah keuangan publik, dan implementasinya dalam sebuah sistem ekonomi. Ia lebih menekankan kepada prinsip keadilan yang mejadi prinsip utama dalam melangsungkan pola pemikirannya itu. Salah satu karya yang terkemuka Abu Ubaid adalah kitab al Amwal, yang mana kitab tersebut pada dasarnya menjelaskan terhadap pelaksanaan distribusi kekayaan secara adil dan merata. Ia juga menawarkan pandangan yang radikal tentang pemberian terhadap seseorang dari para penguasa. Itu diberikan sesuai dengan berapa besarnya pengabdian yang telah diberikan kepada masyarakat itu sendiri, dan juga Abu Ubaid sangat memperhatikan bahwa dalam pendistribusian suatu harta, tidak boleh menguntungkan suatu pihak. Karena itu menurutnya, pemerintah harus mengatur harta kekayaan masyarakat agar selalu difungsikan secara baik agar tercapai kemamkmuran bagi seluruh komponen masyarakat.

\section{Referensi:}

Abdul Islahi Azim. History of Economic Thought in Islam. Aligarh: Aligarh Muslim University, 1996.

Adiwarman A. Karim. Sejarah Pemikiran Ekonomi Islam. Jakarta: Raja Garafindo Persada, 2004.

Amin Karimnia, Mohammad Ali Kharmandar. "The Fundamentals of Constructing a Hermeneutical Model for Poetry Translation.” In Procedia - Social and Behavioral Sciences, 70:580 - 591. Procedia - Social and Behavioral Sciences, 2013.

Bambang Hendarta Suta Purwana. "Pendekatan Hermeneutik Dalam Penafsiran Teks Sastra Melayu.” Humaniora XIII, no. 1 Februari (2001): 82-89. 
Iasmina Petrovici. "Philosophy as Hermeneutics: The World of Text Concept in Paul Ricouer's Hermeneutics." In Procedia - Social and Behavioral Sciences, 71:21-27. Procedia - Social and Behavioral Sciences, 2013.

Imamudin Yuliadi. Ekonomi Islam: Sebuah Pengantar. Yokyakarta: LPPI, 2001.

Natajuddin Siddiqi. Muslim Economics Thinking. Leicester: 1981, Islamic Fondation.

Said Sa'ad Marthon. Ekonomi Islam: Di Tengah Krisis Ekonomi Global. Jakarta: Zikrul Hakim, 2008.

Sejarah Pemikiran Ekonomi Islam. Euis Amalia. Jakarta: Pustaka Asatrus, 2005. 